\title{
Nitrogen Supplementary Feeding with Energy Sources Concentrated in Ettawa Crossbreed Does
}

\author{
Kustantinah Kustantinah ${ }^{1, *}, \mathrm{R} N$ Khoirunnisa ${ }^{2}$, Diah Tri Widayati ${ }^{3}$, Ismaya Ismaya ${ }^{3}$, \\ Ristianto Utomo ${ }^{1}$ and Fajar Ajimukti Atmojo ${ }^{4}$
}

\author{
${ }^{I}$ Department of Animal Nutrition, Faculty of Animal Science, Universitas Gadjah Mada, Yogyakarta, Indonesia, Jl. \\ Fauna No, Bulaksumur, Yogyakarta, Indonesia \\ ${ }^{2}$ Master Student of Animal Science, Faculty of Animal Science, Universitas Gadjah Mada \\ ${ }^{3}$ Departement of Animal Reproduction and Breeding, Fac. of Animal Science, Universitas Gadjah Mada \\ ${ }^{4}$ Department of Animal Science, Faculty of Animal Husbandry, Marine and Fisheries, University of Nusa Cendana, \\ Kupang - Indonesia \\ *Corresponding author. Email: kustantinah@ugm.ac.id
}

\begin{abstract}
The main obstacle of the Ettawa Crossbreed does management at the farm level is that the forages are the only feed given because farmers could not afford the feed supplement, which leads to the inability to reach optimum productivity. In this study, the feed supplement was added as a source of energy in the form of concentrate to increase does productivity. This study used ten Ettawa Crossbreed does with a bodyweight of about $25 \mathrm{~kg}$, divided into two groups. The first group $(n=5)$ was the control group, meaning that the type and the amount of feed given was the usual forage given by farmers, while the second group $(n=5)$ was the treatment group, meaning that the feed given was the usual feed given by farmers with supplementation of energy sources feed in the form of concentrate. Feed treatment was done for eight weeks. In the fifth and sixth weeks, the total collection was carried out. The variables observed in this study were nutrient consumption and nutrient digestibility. The results showed that the supplementation of energy sources increased $(\mathrm{P}<0.05)$ the consumption of total nutrient (forage + concentrate) compared to the control, dry matter consumption of the control and treatment group was $815.60 \pm 94.67$ and $1235.76 \pm 124.28$ gram/head/day, repsectively. Crude protein consumption of the control and treatment groups was $151.65 \pm 11.61$ and $211.28 \pm 22.59 \mathrm{gram} / \mathrm{head} /$ day, repsectively. Total digestible nutrient showed a significantly different $(\mathrm{P}<0.05)$. Meanwhile, the dry matter coefficient digestibility for the control was significantly lower $(\mathrm{P}<0.05)$ compared with treatment group, namely $65.18 \pm 6.43$ and $84.53 \pm 3.67 \%$. Based on the results, it was concluded that supplementary feeding with energy sources concentrate significantly increased the consumption and digestibility of nutrient.
\end{abstract}

Keywords: Ettawa crossbreed does, forage, supplementary feed, energy source.

\section{INTRODUCTION}

Feed is an essential aspect of livestock management. The genetic potential of livestock can be optimum if supported by good environmental factors, such as feeding management and nutrient content before and during mating. Low quality and quantity of feed will cause low livestock productivity, such as slow growth and low body weight. Especially for young livestock, low body weight will delay reaching puberty and low fertility. Therefore, the preparation of the ration components is essential to achieve the optimum growth rate of livestock and reproduction performance. The balance of energy and protein is essential because it can affect the microbial fermentation process in the rumen. The proper balance of protein and energy result in ruminant productivity becomes efficient.

The study of [1] showed a low feed conversion ratio of Kacang Goats given protected Soybean meal (SBM) supplementation treated with formaldehyde, While the study of [2] was showed that the SBM energy is quite high. Concentrate supplementation showed better changes in behaviour during estrus, ovulation rates, pregnancy rates, and better male responses for female goats. Therefore, knowing the proper balance of energy 
and protein is expected to support the livestock's genetic potential to achieve productivity. This study aimed to determine the proper protein and energy supplementation feeding for Ettawa Crossbreed to achieve optimum productivity and reproductive performance and give information about the proper energy supplementation ratio to produce a good production performance by achieving feed efficiency.

\section{MATERIAL AND METHOD}

The livestock used in this study were ready to mate Ettawa Crossbreed does (age \pm 10 months) with an initial weight of $\pm 25 \mathrm{~kg}$. The total number of does used was 10 . The feed consisted of usual feed given by farmers and energy source concentrate feed as the treatment.

The preparation stage included the preparation of the does and pens. Preparation of the cage includes cleaning, and feeder, drinker, and faeces container installation. The ten does use divided into two groups. The first group $(n=5)$ was the control group (the type and the amount of feed given by farmers usually). In contrast, the second group $(n=5)$ was the treatment group (the type and the amount of feed given by farmers usually with supplementation of energy sources in the form of concentrate of $500 \mathrm{grams} / \mathrm{head} / \mathrm{day}$. The nutrient content of concentrate was $12.81 \%$ of dry matter, $13.64 \%$ of crude protein and $77.88 \%$ of total digestible nutrients).

Table 1. Feed Offered

\begin{tabular}{|l|c|c|}
\hline Item & Control & Treatment \\
\hline $\begin{array}{l}\text { Basal feed: Forage (as } \\
\text { farmer usually given } \\
\text { to animals) }\end{array}$ & Ad libitum & Ad libitum \\
\hline Feed Supplement & - & $\begin{array}{l}\text { Energy } \\
\text { source }\end{array}$ \\
\hline
\end{tabular}

The does was adapted with feed for 14 days to maintain the body condition score and eliminate the influence of the last feed. In addition, does was also given deworming before the treatment. The observation and treatment were carried out for two months. The does were kept in individual pens. Feed was given two times a day, at $08.00 \mathrm{am}$ and $4.00 \mathrm{pm}$. Drinking water and forage were provided ad libitum (Table 1), while the concentrate
(Table 3 ) was given according to $2 \%$ of bodyweight or \pm 500 grams/day/head.

The does was adapted with feed for 14 days to maintain the body condition score and eliminate the influence of the last feed. In addition, does was also given deworming before the treatment. The observation and treatment were carried out for two months. The does were kept in individual pens. Feed was given two times a day, at $08.00 \mathrm{am}$ and $4.00 \mathrm{pm}$. Drinking water and forage were provided ad libitum (Table 1), while the concentrate (Table 3 ) was given according to $2 \%$ of bodyweight or \pm 500 grams/day/head.

During the last 14 days of the treatment period, the total collection was carried out by weighing the amount of forage and concentrate, the remaining feed, and the faeces every day. Samples were dried under the sun for two days. Then it was dried at $55^{\circ} \mathrm{C}$. Sample analysis, in the form of dry matter content (DM), organic matter content $(\mathrm{OM})$, crude protein content $(\mathrm{CP})$, crude fat content (EE), and crude fibre $(\mathrm{CF})$, was done using the AOAC method [3]

Table 3. Percentage and chemical composition of concentrate energy source

\begin{tabular}{|l|c|}
\hline Feedstuffs & Energy source (\%) \\
\hline Wheat pollard & 35 \\
\hline Soybean Meal & 14 \\
\hline Kleci & 20 \\
\hline Dry Cassava & 25 \\
\hline Molasses & 5 \\
\hline Premix & 1 \\
Total & 100 \\
\hline Nutrient content (\%) & \\
\hline DM & 84.54 \\
\hline OM & 94.57 \\
\hline CP & 13.64 \\
\hline EE & 2.45 \\
\hline CF & 12.81 \\
\hline NFE & 66.13 \\
\hline TDN & 77.88 \\
\hline
\end{tabular}

Table 2. Chemical composition of feedstuffs (\% DM)

\begin{tabular}{|l|c|c|c|c|c|c|c|}
\hline \multirow{2}{*}{ Feedstuffs } & \multirow{2}{*}{ DM (\%) } & \multicolumn{7}{c|}{ Composition (\%) } \\
\cline { 3 - 9 } & & OM & CP & CF & EE & NFE & TDN \\
\hline Wheat pollard & 88.39 & 94.61 & 13.76 & 10.23 & 4.08 & 66.54 & 76.89 \\
\hline Soybean Meal & 85.74 & 94.78 & 45.59 & 2.63 & 1.12 & 45.44 & 84.14 \\
\hline Kleci & 89.16 & 92.32 & 6.42 & 35.26 & 1.09 & 51.80 & 66.34 \\
\hline Dry cassava & 87.16 & 97.13 & 2.59 & 4.81 & 2.11 & 87.62 & 85.24 \\
\hline Mollases & 39.65 & 85.17 & 5.00 & 0.99 & 1.09 & 78.09 & 78.53 \\
\hline
\end{tabular}


Feed consumption measured included consumed dry matter (DM), crude protein (CP), crude fibre (CF), organic matter $(\mathrm{OM})$, and Total Digestible Nutrient (TDN). Dry matter consumption was calculated by calculating the difference between the amount of feed given and the remaining feed, then multiplied by the DM content of the feed. The $\mathrm{CP}, \mathrm{CF}$, and $\mathrm{OM}$ consumption was calculated by multiplying the DM consumption by each nutrient's nutrient content $(\%)$ in the feed. The equation calculates TDN consumption was: TDN $(\%)=$ $\mathrm{DCP}(\%)+\mathrm{DCF}(\%)+2,25 \times \mathrm{DEE}(\%)+$ DNFEdd $(\%)$.

Digestibility of feed nutrients was calculated by the difference between feed nutrient consumption (DM, OM, $\mathrm{CP}$, and $\mathrm{CF}$ ) with faecal nutrient content (DM, OM, CP, and $\mathrm{CF}$ ). The equation was:

$$
\text { DM digestibility }(\%)=\frac{\text { digested DM }(g r)}{\text { DM consumption }(g r)} \times 100 \%
$$

Data on nutrient consumption and nutrient digestibility were analyzed using a Completely Randomized Design with a one-way ANOVA, followed by Duncan's test if the results showed significant differences.

\section{RESULT AND DISCUSSION}

The supplementation of energy sources in the form of concentrates showed a significant difference $(p<0.05)$ compared to the control group when we only gave forages for feeding (Table 4). It indicated an improvement in the balance of protein and energy in the treatment group. Energy supplementation provided a reasonably high nutrient consumption $(\mathrm{P}<0.05)$. Similar to the study of [4], energy supplementation with corn as a source of supplementation reduces the time of grazing Goats. The goats without corn supplements were grazed for 6.69 hours. Subsequently, the grazing time was decreased for the goat with corn supplementation $(1.3 \%$ of their body weight) to 6.11 hours. It means that the addition of energy supplementation reduced the time of grazing or forage consumption. Molasses supplementation as an energy source showed an increase in daily feed intake. At the same time, the feed conversion ratio was decreased maximum at $40 \%$ molasses supplementation [5].

The coefficient digestibility of the treatment group gave considerably good results, showed a significant increase $(\mathrm{P}<0.05)$ for all nutrients. The forage nutrient digestibility (Table 4) showed a significant increase $(\mathrm{P}<0.05)$ in the treatment group. The supplementation of an energy source with $500 \mathrm{grams} / \mathrm{head} /$ day of concentrate would be caused an increase in forage nutrient digestibility. The escalation reached 9 points (\% digestibility of DM and $\mathrm{CP}$ ). While in the digestibility of $\mathrm{CF}$, the raise was relatively high significantly $(\mathrm{P}<0.05)$, which was almost 40 points (Table 7). Meanwhile, Rahman et al. [5] stated that the combination of palm kernel cake and molasses in goats feed did not affect the digestibility of DM (\%) and CP (\%) when compared with the addition of commercial concentrates.

Table 4. Total Nutrient consumption (Forage + Concentrate) (gram/head/day)

\begin{tabular}{|l|c|c|}
\hline \multicolumn{3}{|c|}{ Consumption (gram/head/day) } \\
\hline \multicolumn{1}{|c|}{ Nutrient } & Control (Forage) & $\begin{array}{c}\text { Treatment } \\
\text { (Forage }+ \\
\text { Concentrate) }\end{array}$ \\
\hline Dried matter & $815.60 \pm 94.67^{\mathrm{b}}$ & $1,235.76 \pm 124.28^{\mathrm{a}}$ \\
\hline $\begin{array}{l}\text { Organic } \\
\text { matter }\end{array}$ & $763.14 \pm 90.34^{\mathrm{b}}$ & $1,160.51 \pm 114.03^{\mathrm{a}}$ \\
\hline $\begin{array}{l}\text { Crude } \\
\text { protein }\end{array}$ & $151.65 \pm 11.61^{\mathrm{b}}$ & $211.28 \pm 22.59^{\mathrm{a}}$ \\
\hline Crude fat & $5.45 \pm 0.65^{\mathrm{b}}$ & $16.46 \pm 1.23^{\mathrm{a}}$ \\
\hline Crude fiber & $193.21 \pm 28.04^{\mathrm{b}}$ & $247.53 \pm 29.14^{\mathrm{a}}$ \\
\hline NFE & $412.82 \pm 50.89^{\mathrm{b}}$ & $687.18 \pm 61.46^{\mathrm{a}}$ \\
\hline TDN & $491.96 \pm 53.25^{\mathrm{b}}$ & $819.95 \pm 73.87^{\mathrm{a}}$ \\
\hline $\begin{array}{l}\text { a,b,c Different superscripts on the same line show differences }(\mathrm{P}<0,05) \\
\text { (a>b) }\end{array}$
\end{tabular}

Table 5. Consumption of forage nutrients (without concentrate)

\begin{tabular}{|l|c|c|}
\hline \multicolumn{1}{|c|}{ Nutrient } & Control (Forage) & $\begin{array}{c}\text { Treatment } \\
\text { (Forage }+ \\
\text { Concentrate) }\end{array}$ \\
\hline Dried matter & $815.60 \pm 94.67$ & $813.06 \pm 124.28$ \\
\hline Organic matter & $763.14 \pm 90.34$ & $760.76 \pm 114.03$ \\
\hline Crude protein & $151.65 \pm 11.61$ & $153.62 \pm 22.59$ \\
\hline Crude fiber & $193.21 \pm 28.04$ & $193.38 \pm 29.14$ \\
\hline NFE & $412.82 \pm 50.89$ & $407.65 \pm 61.46$ \\
\hline TDN & $491.96 \pm 53.25$ & $490.74 \pm 73.87$ \\
\hline a,b,c Different superscripts on the same line show differences $(\mathrm{P}<0,05)$
\end{tabular}
(a>b)

Based on Table 4, a positive result was indicated by the treatment group's increase in forage nutrient digestibility. The provision of energy sources provided a better balance of protein and energy in the rumen for the proliferation of rumen microorganisms. As a result, digestibility was increased (Table 7). 
Table 6. Nutrient digestibility coefficient of control and treatment rations.

\begin{tabular}{|l|c|c|}
\hline \multicolumn{3}{|c|}{ Coefficient digestibility of Nutrient (\%) } \\
\hline Nutrient & Control (Forage) & $\begin{array}{c}\text { Treatment } \\
\text { (Forage }+ \\
\text { Concentrate) }\end{array}$ \\
\hline Dried matter & $65.18 \pm 6.43^{\mathrm{b}}$ & $84.53 \pm 3.67^{\mathrm{a}}$ \\
\hline Organic matter & $66.63 \pm 6.11^{\mathrm{b}}$ & $85.79 \pm 3.29^{\mathrm{a}}$ \\
\hline Crude protein & $84.28 \pm 4.13^{\mathrm{b}}$ & $95.04 \pm 1.32^{\mathrm{a}}$ \\
\hline Crude fat & $55.05 \pm 56.31^{\mathrm{b}}$ & $78.63 \pm 5.21^{\mathrm{a}}$ \\
\hline Crude fiber & $55.45 \pm 6.90^{\mathrm{b}}$ & $78.73 \pm 5.43^{\mathrm{a}}$ \\
\hline NFE & $66.91 \pm 6.70^{\mathrm{b}}$ & $85.69 \pm 3.40^{\mathrm{a}}$ \\
\hline TDN & $61.87 \pm 6.30^{\mathrm{b}}$ & $82.06 \pm 3.20^{\mathrm{a}}$ \\
\hline a,b,c Different superscripts on the same line show differences (P<0,05)
\end{tabular}
$(\mathrm{a}>\mathrm{b})$

Table 7. Forage nutrient digestibility coefficient (without concentrate) (\%) in both groups

\begin{tabular}{|l|c|c|}
\hline Nutrient & Control (Forage) & $\begin{array}{c}\text { Treatment } \\
\text { (Forage }+ \\
\text { Concentrate) }\end{array}$ \\
\hline Dried matter & $68.57 \pm 6.57$ & $76.34 \pm 5.63^{\mathrm{b}}$ \\
\hline Organic matter & $66.98 \pm 6.21^{\mathrm{a}}$ & $78.17 \pm 5.20^{\mathrm{b}}$ \\
\hline Crude protein & $84.42 \pm 4.15^{\mathrm{a}}$ & $93.12 \pm 2.01^{\mathrm{b}}$ \\
\hline Crude fiber & $55.99 \pm 7.27^{\mathrm{a}}$ & $93.12 \pm 7.07^{\mathrm{b}}$ \\
\hline NFE & $67.25 \pm 6.72^{\mathrm{a}}$ & $75.67 \pm 2.99^{\mathrm{b}}$ \\
\hline TDN & $62.15 \pm 6.37^{\mathrm{a}}$ & $73.57 \pm 4.94^{\mathrm{b}}$ \\
\hline a,b,c Different superscripts on the same line show differences $(\mathrm{P}<0,05)$
\end{tabular}
$(\mathrm{a}>\mathrm{b})$

\section{CONCLUSION}

The conclusion showed that supplementation of energy source with a concentrate of 500 grams/head/day positively impacts the consumption of all nutrients $(\mathrm{CP}$, $\mathrm{CF}$, NFE, and TDN) than control groups. As an implication, the digestibility of these nutrients also increases. The Goat group that received feed supplementation as a source of energy increased the consumption and digestibility of nutrients.

\section{ACKNOWLEDGMENTS}

The authors thank the Laboratory of Animal Feed Science, Faculty of Animal Science that has provided all facilities used to perform this research. The authors also sincerely thank Universitas Gadjah Mada for financial support through Rekognisi Tugas Akhir (RTA) 2021 No. 3143/UN1.P.III/DIT-LIT/PT/2021.

\section{REFERENCES}

[1] Adiwinarti, R., I.G.S. Budisatria, K. Kustantinah, R. Rusman, E. Indarto. 2019. Effects of rations containing formaldehydeprotected soybean meal on meat production in Kacang goats. Veterinary World, EISSN: 22310916 Available at www.veterinaryworld.org/Vol.12/June2019/25.pdf

[2] Kustantinah, I.G.S. Budisatria, Rusman and R. Adiwinarti. 2018. Effects of Total Mixed Rations Containing Treated or Untreated Soybean Meal on the Energy Utilization of Kacang Goats. Pakistan Journal of Nutrition ISSN 1680-5194 DOI: $10.3923 /$ pjn.2018.563.567.

[3] AOAC. 2005. Official Methods of Analysis of the Association of Official Analytical Chemists. Published by the Association of Official Analytical Chemist. Marlyand.

[4] Fiares de Carvalho, W., M. Elizabete de Oliveira, A. azevêdo alves, R. Lustosa de Moura, . 2017. Energy supplementation in goats under a silvopastoral system of tropical grasses and leucaena. Revista Ciencia Agronomica 48(1).DOI: 10.5935/1806-6690.20170023

[5] Rahman, M.M, R.B. Abdullah, W.E. Wan Khadijah, T. Nakagawa and R. Akashi. 2013. Feed Intake, Digestibility and Growth Performace of Goats offered Napier grass Supplemented with Molasse Protected Palm Kernel Cake and Soya Waste. Asian J. of Animal and Veterinary Advances 8(3):527-534. 